Fourth International Conference on Sustainable Construction Materials and Technologies http://www.claisse.info/Proceedings.htm

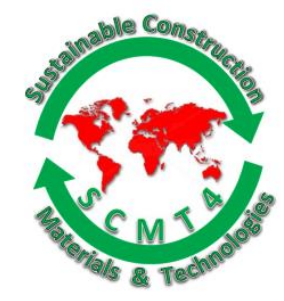

SCMT4

Las Vegas, USA, August 7-11, 2016

\title{
A Comparative Study of Alkali-Activated Fly Ashes under Heat- Exposure
}

\author{
Sepehr Seyedian Choubi ${ }^{1 a}$, Cagla Meral ${ }^{1 b^{*}}$, Yiğit Semih Akbas ${ }^{1 c}$, Meltem Tangüler \\ Bayramtan $^{1 d}$
}

${ }^{1}$ Department of Civil Engineering Middle East Technical University, Ankara 06800, Turkey,

${ }^{1 a}$ Email: <seyedian.choubi@metu.edu.tr>, ${ }^{b}$ Ph.D, Email: <cmeral@metu.edu.tr>,

${ }^{1 c}$ Email:<yigitsemihakbas@gmail.com>, ${ }^{1 d}$ Email: <tmeltem@metu.edu.tr>.

\begin{abstract}
Coal fly ash (FA) is a by-product of combustion processes in coal fired power plants. Annually over 800 million tons of fly ash is being produced all around the world. Only a small portion of this ash is reutilized; a major portion goes to landfills or dumped at the sea. The disposal of FA brings significant economic and environmental concerns. Alkali-activation (AA) of fly ashes is a possible way to put some of the FAs in a beneficial use. Alkali-activated fly ashes (AAFA) possess good mechanical properties, acid and fire resistance and thermal stability. This study aims to evaluate the alkali-activation and heat-exposure performances of FAs with varying Ca-contents from three different thermal power plants in Turkey through compressive strength tests and XRD measurements. The strength development of the AAFA samples were followed by 3-, 7- and 28-day compressive strength tests. The heat-exposure performance of the AAFA samples were determined by measuring the residual compressive strengths of the 28-day old samples after being exposed to elevated temperatures $\left(400,700\right.$ and $\left.1000^{\circ} \mathrm{C}\right)$. It is concluded that not only the amorphous content, but also the fineness of the FA has a critical importance on the strength development of the AAFAs. The AA samples of the FA with highest Ca-content lost considerable strength after exposure to elevated temperatures, possibly due to decomposition of the Ca-bearing phases. The AA samples with medium Cacontent did not show significant changes during heat exposure. The AA samples with low Ca-content showed enhanced performance after being exposed to $400^{\circ} \mathrm{C}$. The role of $\mathrm{Ca}$ in performance of AAFAs under heat-exposure needs to be further studied. The X-ray Diffraction (XRD) patterns of the FAs showed that zeolite type phases has formed during activation. Zeolite phases remained stable during heat treatment until $700^{\circ} \mathrm{C}$. After $700^{\circ} \mathrm{C}$ zeolite type phases started to dehydrate and form stable phases such as Nepheline and Haüyne.
\end{abstract}

\section{INTRODUCTION}

Coal fly ash (FA) is one of the main by-products of combustion of pulverized coal in thermal power plants for production of electricity. It is the part that becomes suspended in plant flue gasses and captured by mechanical or electrical particulate collection devices. With global production of approximately 800 million tonnes annually, it is one of the most available, highly amorphous aluminosilicate waste materials (Bae et 
al., 2014; Celik et al., 2015). However, the reuse ratio is estimated to be around $25 \%$ and the remaining $75 \%$ is disposed (Tangüler, Gürsel, \& Meral, 2015; Tangüler, Meral, \& Aslam, 2014; Tangüler, Meral, \& Gursel, 2014). In Turkey, 23\% of energy production comes from coal-fired thermal power plants in which lignite coal is mostly combusted resulting in $17 \%$ to $46 \%$ ash based on used coal and technology in the thermal power plants. In 2014, it was estimated that approximately 20 million tonnes of FA has been produced in these thermal power plants (Tangüler et al., 2015). However; there is very limited reuse of FA, and most of it is disposed in landfills or dumped to the sea. Properly disposing FA might require high storage area and transportation costs; whereas the improper disposal of the FA may result in potential environmental problems. FAs, generally enriched in potentially toxic elements compared to soils and sediments, might experience leaching of the trace elements contaminating the soil and the ground water. Most FAs are stocked in open fields and this might constitute a threat to near-by people and environment. The very fine FA particles can be suspended in the air with ease and cause air pollution. Furthermore, prolonged exposure to FA may lead to irritation in the human body. Hence, finding sustainable solutions for reutilization of FA is promoted (Tangüler, Meral, \& Gursel, 2014).

The chemical, mineralogical and physical properties of FAs are strongly related to the type and chemical composition of the coal being used, the combustion equipment and the particle collection method (Tangüler, Meral, \& Aslam, 2014). From mineralogical point of view FAs consist of three main phases: highly amorphous aluminosilicate glass, crystalline components, and unburnt carbon (Meral, Benmore, \& Monteiro, 2011; Ward \& French, 2006).

Within the past decade, the interest on alkali-activated fly ashes (AAFA) as an alternative cementitious material has significantly grown (van Deventer et al. 2007). The alkali-activation of FA results in chemically complex processes in which amorphous phase of the ash (sometimes even the crystalline comonents) is converted into a strong binder (Bernal et al. 2011; Duxson, Provis, 2008; Jae Oh et al. 2015). Hydroxides of alkali metals are the most commonly used activators, among which sodium hydroxide is the most-favored due to its performance and reasonable cost (Bernal, van Deventer, \& Provis, 2015; van Deventer et al., 2007).

Previous studies showed that alkali-activation process of FA depends on the chemical nature of FA (composition and amorphous content) (Pacheco-Torgal, Castro-Gomes \& Jalali, 2008), concentration of the activator, the curing conditions (Jae Oh et al. 2015) and particle size. Jae Oh 's studies showed that even though temperature of curing dominates the path of activation but its effects is highly depended on nature of FA and concentration of activator. Studies have shown that additional to curing, particle size distribution of raw FA significantly affects fresh and hardened properties of AAFA. Large portion of alkali activation accrues on the surface of particles; finer fly ash has higher surface area which will lead to producing more binder and consequently higher strength (Bakharev 2006; Çelik, Damc1, and Pi 2008; Jae Oh et al. 2015; Provis, Palomo, and Shi 2015).

Activation is a series of consecutive reactions of destruction-condensation which starts with disintegration of materials and break down of Si-O-Si and Al-O-Si bonds at high PH of the alkaline solution. Then, the fragmented structure starts to agglomerate and turn into a condensed product (Pacheco-Torgal et al., 2008). The nanostructure of alkali activated materials are affected by calcium content (Provis et al., 2015); therefore, understanding the role of calcium during activation of materials (even with the low-calcium materials such as low-limeFA) is essential to study of the formation of geopolymers (Bernal et al., 2015). Researches indicate that activation of high-calcium materials such as slag are intended to result in calcium aluminosilicate hydrate $(\mathrm{C}-\mathrm{A}-\mathrm{S}-\mathrm{H})$ while activation of the lowcalcium materials are most likely to produce an alkali aluminosilicate (N-A-S-H) gel (Provis et al. 2015). 
(Oh, Monteiro, Jun, Choi, \& Clark, 2010) found that lime content of high-lime FA in activation process acts differently considering other types of pozzolans such as slag. Activated high-lime FA with sodium hydroxide has resulted in lower strength compared to slag and low-lime FA which could be drawn from defective dissolution of calcium in activator solution.

Alkali-activated binders are inorganic materials with chemical and physical water bound in. Studies have concluded that alkali-activated binders have ceramic like properties and they are less vulnerable in high temperatures compare to portland cement based binders (F. Pacheco-Torgal, J. Labrincha and C. Leonelli 2014). (Bernal et al., 2011) results showed elevated temperature up to $1000^{\circ} \mathrm{C}$ has resulted in contribution to compressive strength which was outcome of restructuration and reformation of geopolymers. (Bernal et al., 2015) experiments on different types of activators indicated that compare to sodium and potassium, rubidium and cesium based activators tend to produce additional aluminosilicate crystalline, their thermal tests suggested that stability of activated specimens were highly depended on alkaline radius and degree of ordering of geopolymers. (Martin, Pastor, Palomo, \& Fernández Jiménez, 2015) comparative tests on changes in strength of Portland cement paste and alkali activated low lime FA at high temperature indicated while cement strength values decline after $400^{\circ} \mathrm{C}$ and fades at $1000^{\circ} \mathrm{C} F A$ shows much more resistance.

This study investigated the properties of sodium hydroxide activation of high lime and low lime FAs collected from three different power plants in Turkey. Activated FAs heat treated up to 80, 400, 700 and $1000{ }^{\circ} \mathrm{C}$ during which compressive strength development and microstructural changes monitored.

\section{MATERIALS AND METHODS}

Materials. FAs used in this study were obtained from three different coal-fired thermal power plants located in Turkey: Kemerköy, İçdaş and Çatalağzı. Chemical compositions of the FAs are determined by $\mathrm{X}$-ray fluorescence (XRF) spectrometry, and summarized in the Table 1. Reactive silica (the soluble portion of $\mathrm{SiO} 2$ after treatment with hydrochloric acid and potassium hydroxide solution) and reactive calcium oxide of FAs were also measured according to EN 197-1. Kemerköy, İçdaş and Çatalağzı, had 29.3, 36.3 and $42.3 \%$ reactive silica and $23.1,12.0$ and $1.0 \%$ reactive calcium oxide (the fraction of the $\mathrm{CaO}$ which under normal hardening conditions can form calcium-silicate-hydrates or calcium-aluminate-hydrates) respectively.

Table 1. Chemical composition of fly ashes, weight \%

\begin{tabular}{|l|r|r|r|r|r|r|r|r|}
\hline Fly Ash & $\mathrm{SiO}_{2}$ & $\mathrm{Al}_{2} \mathrm{O}_{3}$ & $\mathrm{Fe}_{2} \mathrm{O}_{3}$ & $\mathrm{CaO}$ & $\mathrm{MgO}$ & $\mathrm{SO}_{3}$ & L.O.I. & $\mathrm{Al}_{2} \mathrm{O}_{3}: \mathrm{CaO}: \mathrm{SiO}_{2}$ \\
\hline Kemerköy & 36.7 & 18.6 & 8.0 & 26.2 & 2.2 & 4.2 & 0.4 & $0.50: 0.70: 1.00$ \\
\hline İçdaş & 46.1 & 18.1 & 10.1 & 14.1 & 4.4 & 3.1 & 0.6 & $0.40: 0.30: 1.00$ \\
\hline Çatalağz1 & 56.1 & 25.0 & 5.9 & 1.7 & 2.2 & 0.1 & 2.6 & $0.45: 0.03: 1.00$ \\
\hline
\end{tabular}

The mineralogical phases of the used FAs are determined by X-ray diffraction, Figure 1. The broad hump in Çatalağzı FA $\left(2 \Theta: 20^{\circ}-30^{\circ}\right)$ is more predominant then the humps in other FAs suggesting a more amorphous nature. The Kemerköy has smallest hump suggesting a more crystalline nature.

The particle size distributions (PSD) of the fly ashes were determined as relative volume of particles in size bands using Malvern Mastersizer 2000 laser diffraction equipment at Turkish Cement Manufacturer Association. Measured particle size distribution curves of the FAs are shown in Figure 2. Determined volume mean diameter D[4,3] of the FAs are 66.7, 52.7 and $123.0 \mu \mathrm{m}$ for Kemerköy, İçdaş and Çatalağzı respectively. Çatalağzı is a much coarser than Kemerköy and İçdaş, İçdaş being the finest.

According to the ASTM 618 C, two of the chosen FAs (Kemerköy and İçdaş) can be classified as Class C and one FA (Çatalağzi) can be classified as Class F. 10 M Sodium Hydroxide (NaOH) was chosen as the 
alkali-activator. The activator solutions were prepared by using semiconductor grade $\mathrm{NaOH}$ pellets approximately 1 day before being used.

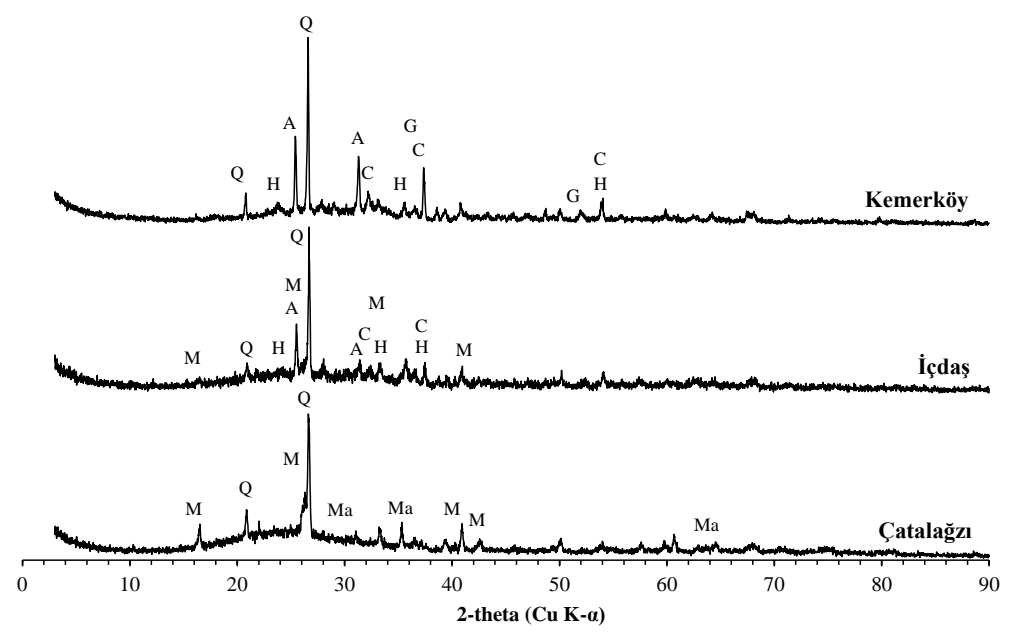

Figure 1. X-ray diffraction patterns of the Kemerköy, İçdaş and Çatalağzı fly ashes

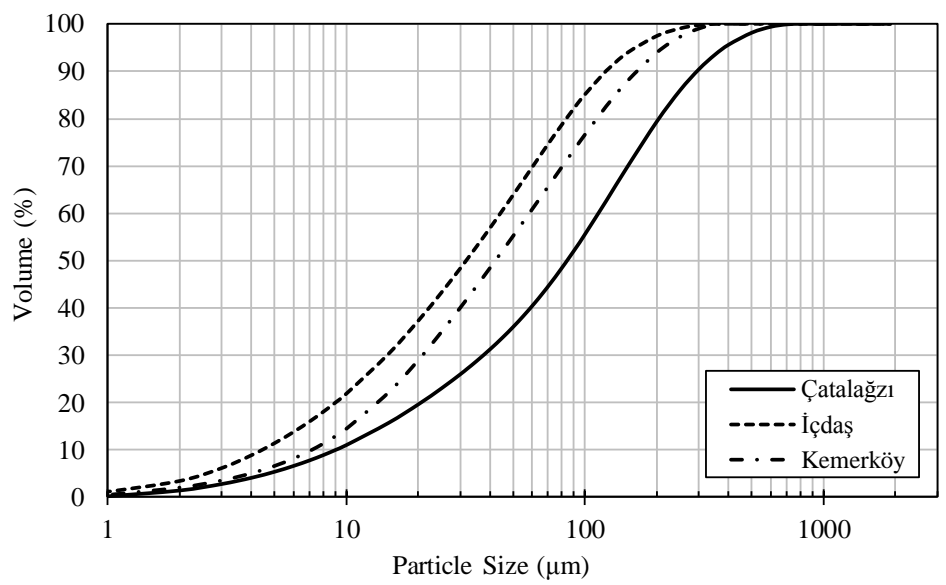

Figure 2. Particle size distribution of the Kemerköy, İçdaş and Çatalağzı fly ashes

Sample preparation. A set of AAFA samples were prepared by combining the $10 \mathrm{M} \mathrm{NaOH}$ solution with the FAs at a solution-to-fly ash ratio of 0.5 , mixing the ingredients for 2 minutes at a standard mixer, casting the mixture into $5 \times 5 \times 5 \mathrm{~cm}$ cubic molds, and then curing the samples at $80^{\circ} \mathrm{C}$ for 24 hours. After the first day, the samples were demolded and were kept in a moist chamber at the ambient temperature $\left(23 \pm 2^{\circ} \mathrm{C}\right)$ and $99 \%$ relative humidity to the test day.

Experimental methods. This study had two experimental phases. In the first phase, compressive strengths of the AAFA samples were measured at 3-, 7- and 28-days of curing. In the second phase, 3 sets of 28-day old samples were exposed to elevated test temperatures $\left(400^{\circ} \mathrm{C}, 700^{\circ} \mathrm{C}\right.$ and $\left.1000^{\circ} \mathrm{C}\right)$ in a high temperature furnace. The used furnace had a fixed heating procedure: heating up to $580^{\circ} \mathrm{C}$ at $60^{\circ} \mathrm{C}$ per hour, and then heating up to $1320^{\circ} \mathrm{C}$ at maximum power. The dwell times at the test temperatures were kept constant as 1 hour, and then the sample sets were cooled naturally in the furnace. After cooling to room temperature, the 
residual compressive strengths of the heat-exposed samples were determined. The compressive strength tests were conducted by using a universal testing machine.

In order to follow the mineralogical changes due to activation and heat-exposure of AAFAs, X-ray diffraction (XRD) measurements were conducted on the pulverized 28-day old and heat-exposed AAFA samples. The measurements were performed on a Rigaku XRD instrument located at the METU Central Laboratory with incident beam of $\mathrm{CuK} \alpha(\lambda=1.5418 \AA)$ radiation with a $2 \Theta$ scanning range of $3^{\circ}$ to $90^{\circ}$.The analysis on the obtained data was conducted using PANnaltical X'Pert High Score Plus software with PDF2 database.

\section{RESULTS AND DISCUSSIONS}

Strength evolution. Measured compressive strengths of the AAFA cubes are shown in Figure 3. For all AAFA samples the strength increased with age. However, none of the samples showed outstanding compressive strength development over time. The compressive strengths of the Çatalağzı samples yielded the weakest results with 3.1, 5.5 and 6.4 MPa for 3, 7 and 28 days respectively. The Kemerköy and İçdaş samples resulted in similar strengths with 9.8 and $8.8 \mathrm{MPa}$ for 3 days and 9.9 and $10.0 \mathrm{MPa}$ for 7 days respectively. İçdaş samples, 13.3 MPa, performed slightly better than Kemerköy samples, $11.2 \mathrm{MPa}$, at 28 days. Considering the activation conditions are the same, the differences in compressive strength can be attributed to the physical, chemical and mineralogical differences of the FAs. Calcium in FA doesn't necessarily be involve in geopolymer formation. It could remain unreacted; and, even cause a reduction in strength. Contribution of calcium is highly depended on its chemical form in the raw FA (Oh et al., 2010). Even though the Çatalağzı FA had the highest amount of reactive silica, it was considerably coarser compared to the other FAs which might explain the relatively lower results. İçdaş FA was slightly finer and has higher reactive silica content compared to Kemerköy FA which might explain the slightly higher results for 7 and 28 days. The slightly higher 3-day result of Kemerköy FA might be due to higher Ca content.

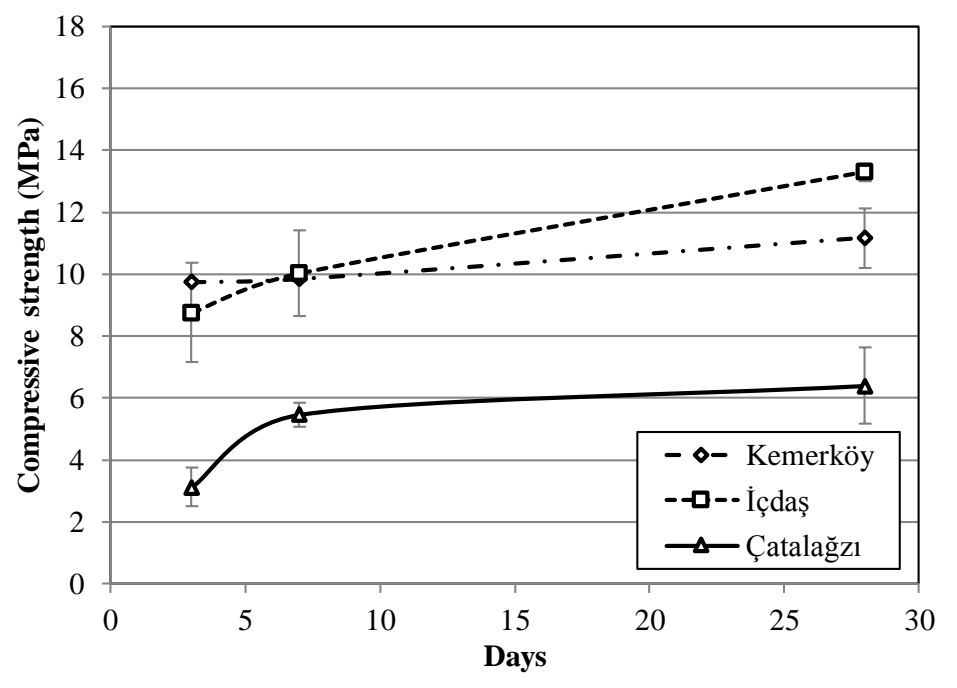

\section{Figure 3. Compressive strength evolution for alkali-activated fly ashes.}

Qualitative observations after heat-exposure. The photographs of the AAFA samples before and after heat-exposure are shown in Figure 4. The samples initially have gray color. After exposure to $700^{\circ} \mathrm{C}$, samples showed a slight change of color from gray to yellow-pink. After being exposed to $1000^{\circ} \mathrm{C}$, Çatalağzı samples turned in to dark terrace cotta color, İçdaş and Kemerköy samples turned slightly yellowish. The İçdaş and Kemerköy samples did not show significantly visible shrinkage cracks when exposed to $1000^{\circ} \mathrm{C}$, whereas the Çatalağzı samples had visible shrinkage cracks even at $700^{\circ} \mathrm{C}$. Also, after 
the heat-exposure Çatalağzı sample shrank considerably. New methods of casting, compacting and heatexposure of the samples might yield in higher performance results.

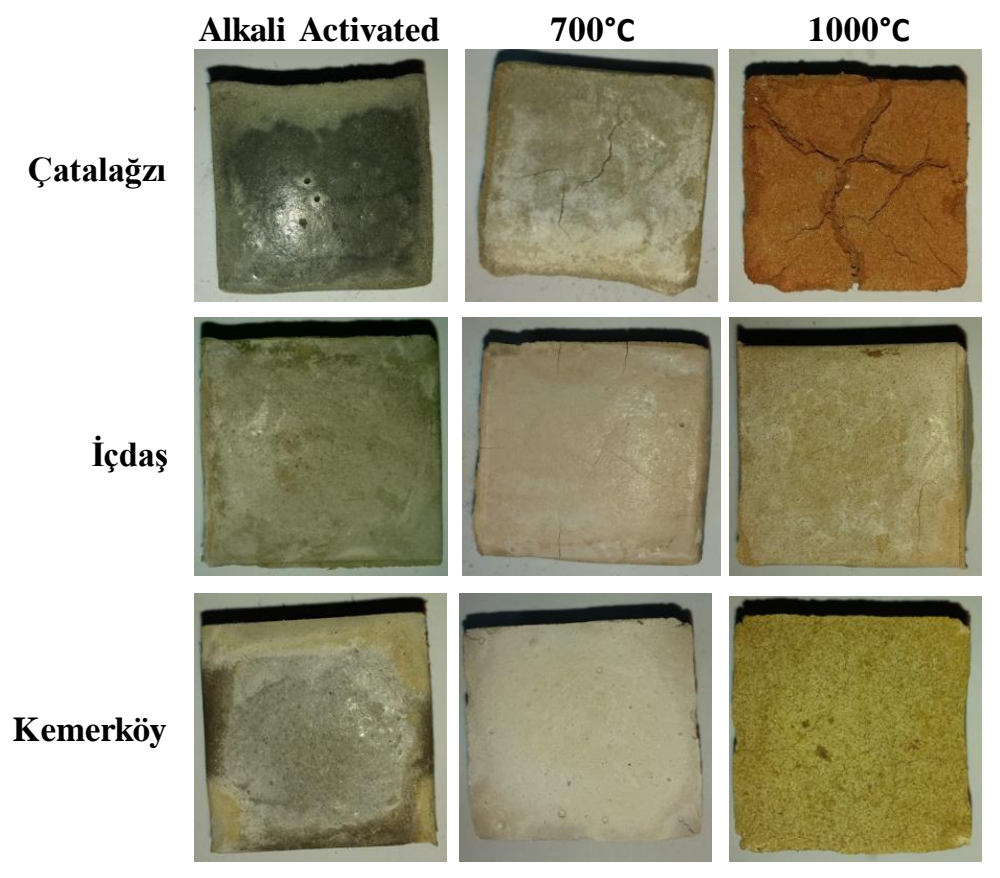

Figure 4. Photographs of alkali-activated fly ash samples before and after heat-exposure.

Residual compressive strength. Figure 5 shows the residual compressive strengths of the 28-day old AAFA samples after heat-exposure to elevated temperatures of 400,700 and $1000^{\circ} \mathrm{C}$.

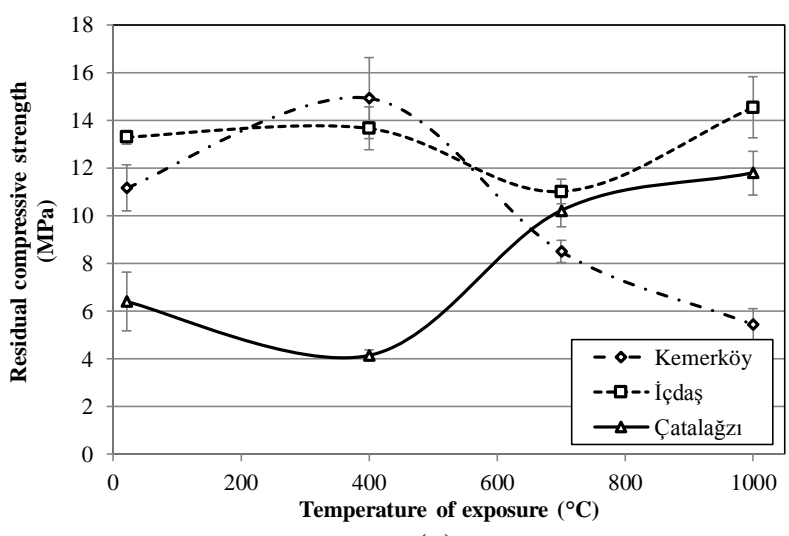

(a)

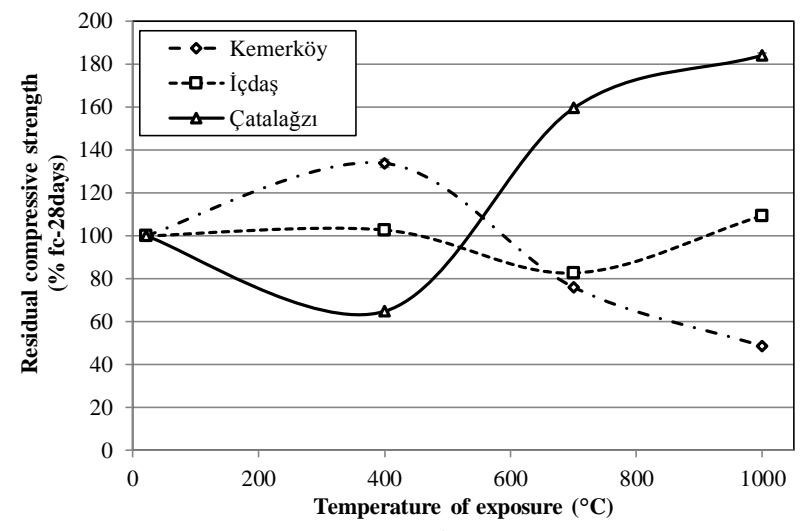

(b)

Figure 5. Residual compressive strengths for alkali-activated fly ashes after heat-exposure (a) in MPa, (b) in \% of 28-day compressive strength at $23^{\circ} \mathrm{C}$.

All of the AAFAs behaved differently when exposed to elevated temperatures. For Çatalağzı FA - the FA with the lowest $\mathrm{Ca}$, highest reactive silica content -, the samples exposed to $400^{\circ} \mathrm{C}$ lost $35 \%$ of the initial strength; but, the samples exposed to 700 and $1000^{\circ} \mathrm{C}$ gained $60 \%$ and $84 \%$ respectively. The İçdaş FA samples did not yield in as significant changes with changes of $+3 \%,-7 \%$ and $+9 \%$ in compressive strength after exposure to 400,700 and $1000^{\circ} \mathrm{C}$ respectively. For Kemerköy FA - the FA with highest Ca and lowest reactive silica content, the samples exposed to $400^{\circ} \mathrm{C}$ gained $34 \%$ of the initial strength; but, the samples 
exposed to 700 and $1000^{\circ} \mathrm{C}$ lost $24 \%$ and $51 \%$ respectively. This might be explained by microcracking in Ca-rich alkali-activated binders exposed to high temperatures and possible decomposition of Ca-bearing phases (possibly including C-A-S-H gels) in the samples (Bernal et al., 2011). More controlled experiments on different FAs needs to be conducted in order to fully comprehend the differences in the residual compressive strengths of AAFAs.

\section{X-ray powder diffraction}

XRD was used to understand the possible mineralogical changes in the AAFAs due to exposure to elevated temperatures.

Figure 6 presents XRD pattern of the raw FAs, and AAFAs before and after heat exposure.
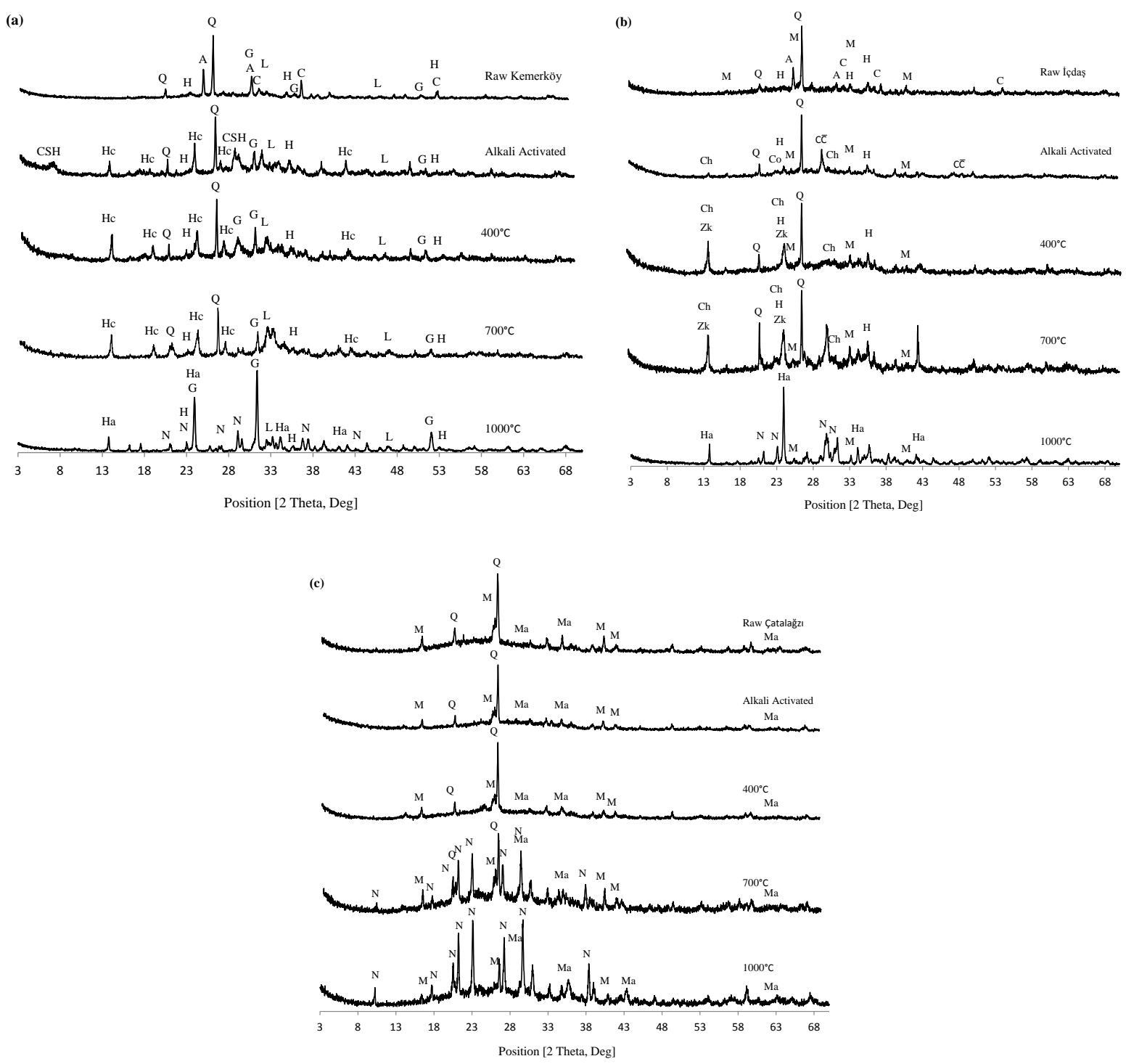

Figure 6. X-ray diffraction patterns of (a) Kemerköy (b) İçdaş (c) Çatalağzı. Q: Quartz, M: Mullite, H: Hematite, Ma: Magnetite, A: Anhydrite, L: Larnite, C: CaO, C $\bar{C}$ : Calcite, 


\section{G:Gehlenite, CSH: C-S-H (I), Hc: Hydroxycancrinite, N: Nepheline, Ch: Chabazite, ZK: Zeolite ZK-14, Ha: Haüyne.}

The activation of the Quartz, Hematite/Magnetite and Mullite were common crystalline phase of FAs which were scantly affected during activation and heat exposure. Hematite/Magnetite and Mullite peaks remained stable during heat-exposure; whereas Quartz peaks disappeared at $1000^{\circ} \mathrm{C}$ in all three FAs. This indicated quartz decomposition in somewhere between $700-1000^{\circ} \mathrm{C}$. Anhydrite peaks in both Kemerköy and İçdaş FAs disappeared completely after activation which indicates that sulfate has entered to other crystalline or amorphous phases.

In the alkali-activated Kemerköy FA, the presence of C-S-H (I) seems possible due to broad peaks around $7^{\circ}$ and $29^{\circ} 2 \Theta$. C-S-H (I) is common in activation of pozzolans with high-calcium content, specially slags (Jea Oh et al. 2010). C-S-H (I) peaks have become very weak after heating up to $400^{\circ} \mathrm{C}$; and, they completely fade at 700 and $1000^{\circ} \mathrm{C}$. Zeolites were formed in all three FAs as activation products. Hydroxycancrinite $\left(\mathrm{Na}_{8} \mathrm{Al}_{6} \mathrm{Si}_{6} \mathrm{O}_{24}(\mathrm{OH})_{2} \cdot 2 \mathrm{H}_{2} \mathrm{O}\right)$ - a member of the ABC-6 types of zeolites - has been detected in activated high-calcium fly ashes (Moutsatsou et al. 2006). Hydroxycancrinite is major phase after activation of Kemerköy which was stable till $700{ }^{\circ} \mathrm{C}$; but, most of the peaks fade at $1000{ }^{\circ} \mathrm{C}$ and Nepheline $\left(\mathrm{NaAlSiO}_{4}\right)$ peaks started to develop. Gehlenite $\left(\mathrm{Ca}_{2}\left(\mathrm{Al}_{2} \mathrm{SiO}_{7}\right)\right)$, a member of melilite group (Hoschek, 1974) - has been detected in high-calcium fly ashes (S.Grzeszczyk, G.Lipowski, 2013). It was also detected in Kemerköy FA. It remained stable during activation and heating process; and, its peaks' intensity increased considerably at $1000^{\circ} \mathrm{C}$. Larnite $\left(\beta-\mathrm{C}_{2} \mathrm{~S}\right)$ presents in Kemerköy FA and remains stable through activation and heat exposure. Observing Larnite's contribution to strength requires longer curing periods than 28 days which was the testing age in this study (Mehta \& Monteiro, 2006). XRD measurements on activated İçdaş FA showed Chabazite $\left(\mathrm{Ca}_{2}\left(\mathrm{Al}_{4} \mathrm{Si}_{8}\right) \mathrm{O}_{24} \cdot 13 \mathrm{H}_{2} \mathrm{O}\right)$ and Zeolite $\mathrm{ZK}-14$ peaks (other types of $\mathrm{ABC}-6$ of zeolites). These zeolite phases remained stable during heat-exposure up until $700^{\circ} \mathrm{C}$; but, after that point they went through dehydration and recrystallization to form more stable phases such as Nepheline and Haüyne $\left(\mathrm{Na}_{3} \mathrm{Ca}\left(\mathrm{Si}_{3} \mathrm{Al}_{3}\right) \mathrm{O}_{12}\left(\mathrm{SO}_{4}\right)\right.$ ) (Rashad \& Zeedan, 2011). In activated Çatalağzı FA, a newly formed strongly crystalline phase was not observed. However, upon heating, Nepheline started to form and become the dominate crystal phase at $1000^{\circ} \mathrm{C}$. This trend on Class F FA was also observed by other researcher (Fernández-Jiménez, Palomo, Pastor, \& Martín, 2008; Fernández-Jiménez, Pastor, Martín, \& Palomo, 2010).

\section{CONCLUSION}

In this study, alkali-activation and heat-exposure performances of fly ashes with varying Ca-contents from three different thermal power plants in Turkey were investigated through compressive strength tests and XRD measurements.

The compressive strength development of alkali-activated Çatalağzı FA was the slowest. Even though this FA was the most amorphous FA with the lowest Ca-content, it was significantly coarser then the other two FAs which might explain the lower strength results of the alkali-activated samples. The İçdaş FA had lower Ca-content than the Kemerköy FA, but it was slightly finer. The İçdaş FA samples demonstrated better strength development than the Kemerköy samples which indicates that high-calcium contents won't necessarily reflect on enhanced mechanical performance. The heat-exposed Çatalağzı samples showed reduced residual compressive strengths at $400^{\circ} \mathrm{C}$. However, even though significant shrinkage cracks were observed in the samples at 700 and $1000^{\circ} \mathrm{C}$; the residual strengths of the samples increased considerably. The İçdaş samples did not demonstrate significant strength changes and showed limited visual cracks during heat-exposure. The residual compressive strength of the Kemerköy samples reduced substantially after heat-exposure. 
FAs produced zeolite type phases during activation. Zeolite phases remained stable during heat treatment until $700^{\circ} \mathrm{C}$. After $700^{\circ} \mathrm{C}$ zeolite type phases started to dehydrate and form stable phases such as Nepheline and Haüyne.

\section{REFERENCES}

Bae, S., Meral, C., Oh, J., Moon, J., Kunz, M., \& Monteiro, P. J. M. (2014). Characterization of morphology and hydration products of high-volume fly ash paste by monochromatic scanning X-ray micro-diffraction ( $\mu$-SXRD). Cement and Concrete Research, 59, 155-164. doi:10.1016/j.cemconres.2014.03.001

Bakharev, T. (2006). Thermal behaviour of geopolymers prepared using class F fly ash and elevated temperature curing. Cement and Concrete Research, 36(6), 1134-1147. doi:10.1016/j.cemconres.2006.03.022

Bernal, S. A., Rodríguez, E. D., Mejía De Gutiérrez, R., Gordillo, M., \& Provis, J. L. (2011). Mechanical and thermal characterisation of geopolymers based on silicate-activated metakaolin/slag blends. Journal of Materials Science, 46(16), 5477-5486. doi:10.1007/s10853-011-5490-z

Bernal, S. A., van Deventer, J. S. J., \& Provis, J. L. (2015). What happens to 5 year old metakaolin geopolymers' the effect of alkali cation. In K. Scrivener \& A. Favier (Eds.), Proceedings of the $1^{\text {st }}$ International Conference on Calcined Clays for Sustainable Concrete (Vol. 10). doi:10.1007/978-94017-9939-3

Celik, K., Meral, C., Gursel, P., Mehta, P. K., Horvath, A., \& Monteiro, P. J. M. (2015). Mechanical Properties, Durability, and Life-Cycle Analysis of Self-consolidating Concrete Mixtures Made with Blended Portland Cements Containing Fly Ash and Limestone Powder. Cement and Concrete Composites, 56, 59-72.

Çelik, Ö., Damc1, E., \& Pi, S. (2008). Characterization of fly ash and it effects on the compressive strength properties of Portland cement. Indian Journal of Engineering \& Materials Sciences, 15(October), 433-440.

Duxson, P., \& Provis, J. L. (2008). Designing precursors for geopolymer cements. Journal of the American Ceramic Society, 91(12), 3864-3869. doi:10.1111/j.1551-2916.2008.02787.x

F. Pacheco-Torgal, J. Labrincha, C. Leonelli, A. P. and P. C. (2014). Handbook of Alkali-Activated Cements, Mortars and Concretes (Vol. 20). Elsevier Science.

Fernández-Jiménez, A., Palomo, A., Pastor, J. Y., \& Martín, A. (2008). New cementitious materials based on alkali-activated fly ash: Performance at high temperatures. Journal of the American Ceramic Society, 91(10), 3308-3314. doi:10.1111/j.1551-2916.2008.02625.x

Fernández-Jiménez, A., Pastor, J. Y., Martín, A., \& Palomo, A. (2010). High-temperature resistance in alkali-activated cement. Journal of the American Ceramic Society, 93(10), 3411-3417. doi:10.1111/j.1551-2916.2010.03887.x

Grzeszczyk, S., \& Lipowski, G. (2013). Effect of content and particle size distribution of high-calcium fly ash on the rheological properties of cement pastes. Journal of Chemical Information and Modeling, 53(9), 1689-1699. doi:10.1017/CBO9781107415324.004

Hoschek, G. (1974). Gehlenite Stability in the System $\mathrm{CaO}--\mathrm{Al}_{2} \mathrm{O}_{3}--\mathrm{SiO}_{2} \sim \mathrm{H}_{2} \mathrm{O}--\mathrm{CO}_{2}$. Contrib. Mineral. Petrol. 47, 245--254 (1974), 254.

Martin, A., Pastor, J. Y., Palomo, A., \& Fernández Jiménez, A. (2015). Mechanical behaviour at high temperature of alkali-activated aluminosilicates (geopolymers). Construction and Building Materials, 93, 1188-1196. doi:10.1016/j.conbuildmat.2015.04.044 
Mehta, P. K., \& Monteiro, P. J. M. (2006). Concrete:Microstructure, Properties, and Materials. Berkeley:McGraw-Hill.

Meral, C., Benmore, C. J., \& Monteiro, P. J. M. (2011). The study of disorder and nanocrystallinity in C$\mathrm{S}-\mathrm{H}$, supplementary cementitious materials and geopolymers using pair distribution function analysis. Cement and Concrete Research, 41(7), 696-710. doi:10.1016/j.cemconres.2011.03.027

Moutsatsou, A., Stamatakis, E., Hatzitzotzia, K., \& Protonotarios, V. (2006). The utilization of Ca-rich and Ca-Si-rich fly ashes in zeolites production. Fuel, 85(5-6), 657-663. doi:10.1016/j.fuel.2005.09.008

Oh, J. E., Jun, Y., Jeong, Y., \& Monteiro, P. J. M. (2015). The importance of the network-modifying element content in fly ash as a simple measure to predict its strength potential for alkali-activation. Cement and Concrete Composites, 57, 44-54. doi:10.1016/j.cemconcomp.2014.12.001

Oh, J. E., Monteiro, P. J. M., Jun, S. S., Choi, S., \& Clark, S. M. (2010). The evolution of strength and crystalline phases for alkali-activated ground blast furnace slag and fly ash-based geopolymers. Cement and Concrete Research, 40(2), 189-196. doi:10.1016/j.cemconres.2009.10.010

Pacheco-Torgal, F., Castro-Gomes, J., \& Jalali, S. (2008). Alkali-activated binders: A review. Construction and Building Materials, 22(7), 1305-1314. doi:10.1016/j.conbuildmat.2007.10.015

Provis, J. L., Palomo, A., \& Shi, C. (2015). Advances in understanding alkali-activated materials. Cement and Concrete Research, 78, 110-125. doi:10.1016/j.cemconres.2015.04.013

Rashad, A. M., \& Zeedan, S. R. (2011). The effect of activator concentration on the residual strength of alkali-activated fly ash pastes subjected to thermal load. Construction and Building Materials, 25(7), 3098-3107. doi:10.1016/j.conbuildmat.2010.12.044

Tangüler, M., Gürsel, A. P., \& Meral, Ç. (2015). Türkiye ' de Uçucu Küllü Betonlar İçin Yaşam Döngüsü Analizi. In 9. Ulusal Beton Kongresi (pp. 431-441).

Tangüler, M., Meral, C., \& Aslam, I. (2014). Early-Age Performance of Binary Fly Ash- Portland Cement Blends. In Eurasia 2014 Waste Management Symposium, 28-30 April (pp. 1-10).

Tangüler, M., Meral, C., \& Gursel, A. P. (2014). Merging Mechanical and Environmental Performance of Turkish Fly Ash-Portland Cement Mortars. In 11th International Congress on Advances in Civil Engineering, 21-25 October (pp. 1-8).

van Deventer, J. S. J., Provis, J. L., Duxson, P., \& Lukey, G. C. (2007). Reaction mechanisms in the geopolymeric conversion of inorganic waste to useful products. Journal of Hazardous Materials, 139(3), 506-513. doi:10.1016/j.jhazmat.2006.02.044

Ward, C. R., \& French, D. (2006). Determination of glass content and estimation of glass composition in fly ash using quantitative X-ray diffractometry. Fuel, 85(16 SPEC. ISS.), 2268-2277.

doi:10.1016/j.fuel.2005.12.026 